\title{
EFFECTIVENESS OF COOPERATIVE LEARNING MODEL TYPE OF NUMBERED HEADS TOGETHER (NHT) WITH THINK PAIR SHARE (TPS) TYPE TOWARDS MATHEMATICS LEARNING OUTCOMES IN STUDENTS CLASS VIII IN SMP NEGERI 2 SLEMAN
}

\author{
Sri Kurniawati ${ }^{\text {a }}$, Uswatun Khasanah ${ }^{\text {b }}$ \\ ${ }^{a}$ Mathematics Education Study Program FKIP UAD \\ Jln. Ringroad Selatan, Tamanan, Banguntapan, Bantul, Yogyakarta \\ asrikurniawati.sk1@gmail.com, ${ }^{\text {buswatun.khasanah2@yahoo.co.id }}$
}

\begin{abstract}
The teacher-centered learning process makes the students less active and does not dare to express their opinion. It affects the result of students' mathematics learning. This research aims to determine the effectiveness of cooperative learning model NHT and TPS type compared with the Direct Learning type toward the result of students' mathematics learning. The type of study in this research is experimental research. The population of the research is all students in grade VIII SMP Negeri 2 Sleman in the academic year 2015/2016. The purposive sampling is used as a sampling technique, derived class VIII C as the experimental class I, class VIII D as the experimental class II and class VIII A as the control class. The data collection technique is documentation and tests. The instrument used is the test question of mathematics learning results. The prerequisite test analysis is the normality test and homogeneity test. Data analysis for hypothesis testing uses the $\mathrm{F}$ test continued Newman-Keuls Test Range. Research result with a significance level of $5 \%$ and $d f=91$ shows (1) There are differences in mathematics learning outcomes of students using cooperative learning model NHT, SMT type and the type of Learning Direct $F_{\text {count }}=3,7643$ and $F_{0,05(2,91)}=3,0966$ to $3,7643>3,0966$ and (2) the results of students learning mathematics using cooperative learning model NHT and TPS type is better than the results of students' mathematics learning that uses the type of Direct Learning. It is indicated by the results of the NewmanKeuls Test Range that is the case I $\overline{y_{1}}-\overline{y_{2}}=0,0005$ and RST $=0,0405$ then $0,0005<0,0405$ so $H_{0}$ acceptable means $\mu_{1}=\mu_{2}$. In case II $\overline{y_{1}}-\overline{y_{3}}=0,0471$ and RST $=0,0470$ then $0,0471>0,0470$ so $H_{0}$ rejected and $\left(\overline{y_{1}}=1,9472\right.$ dan $\overline{y_{3}}=1,9001$ then $1,9472>1,9001$ means $\mu_{1}>\mu_{3}$. Whereas in the case of III $\overline{y_{2}}-\overline{y_{3}}=0,0466$ and RST $=0,0405$ then $0,0466>0,0405$ so $H_{0}$ rejected and $\overline{y_{2}}=$ 1,9467 dan $\overline{y_{3}}=1,9001$ then $1,9467>1,9001$ means $\mu_{2}>\mu_{3}$. So $\mu_{1}=\mu_{2}>\mu_{3}$.
\end{abstract}

Keywords: effectiveness, cooperative learning model NHT type, TPS type, and Direct Instruction type.

\section{INTRODUCTION}

Education aims to create quality human resources to be the next generation that is intelligent and able to compete with other countries, both in the economic, social and especially in the field of education. In addition, the next generation is required to get early education so they can prepare themselves for the advancement of science and technology. Schools are educational facilities that are used to provide learning and science experiences for students and shape students' personalities so students can grow and develop according to their potential. This knowledge was instilled early on in children, from elementary schools to universities. Many new sciences will emerge or old sciences that increase or expand in scope and even experience renewal.

Mathematics subjects are always available subjects from elementary school to university. Mathematics is a science that trains human critical thinking and develops students' activeness and creativity. Mathematics has an important role in the development of technology so that every student is expected to be able to master mathematics. According to James and James in Suherman, Erman, et al. (2003: 16-17) that mathematics is the science of logic regarding form, arrangement, magnitude, and concepts that relate to one another with a large number which are divided into three fields, namely algebra, analysis, and geometry.

In the learning process, students are expected to actively participate in their activities but in reality, students are lazy to follow the learning process, especially when learning mathematics. This is caused by a lack of students' interest in mathematics because students assume that mathematics is 
difficult and boring even though some of the students are enthusiastic about mathematics. Based on interviews conducted by researchers on October 28, 2015, to mathematics teachers at SMP Negeri 2 Sleman, that some students are less interested in taking mathematics lessons so students are not enthusiastic about learning mathematics even though some students already have enthusiasm for mathematics. This can be seen in the value of UTS in the even semester of SMP 2 Sleman. Usually, the class is only dominated by several students and other students are still passive. Most students have not dared to express their opinions. In addition, students also rarely do homework given by the teacher. According to one grade VIII students, these students did not dare to ask questions about material that was not understood. The student also admitted that he often did Homework at school by copying the results of his friend's work.

The cooperative learning model is a learning model that invites students to be more active in learning activities, namely with group work activities where the teacher only gives direction to students and assigns tasks or questions to be done by students and prepares materials and information that will help students solve problems or the task in question. Suprijono, Agus (2009: 54) states that cooperative learning is a broader concept covering all types of group work including forms that are more led by the teacher or directed by the teacher. Cooperative learning models will be able to foster effective learning, namely learning characterized: (1) facilitate students to learn something useful such as facts, skills, values, concepts and how to live in harmony with each other; (2) knowledge, values and skills are recognized by those who are competent to assess. The cooperative learning model includes Numbered Heads Together (NHT) type and Think Pair Share (TPS) type.

NHT type cooperative learning was developed by Spenser Kagan. According to Shoimin, Aris (2014: 108) that Numbered Heads Together is a model of group learning that each member of his group is responsible for his group's tasks, so there is no separation between one student and another student in one group to give and receive one with others. The steps of the NHT cooperative learning model are as follows.

Stage 1: Numbering.

Students are divided into groups of 4 students and each group member is numbered 1,2,3 and 4.

Stage 2: Asking Questions.

The teacher shares the questions with each group.

Stage 3: Think Together.

Each group discusses the answer or unites opinions and ensures each group member can do it.

Stage 4: Answer.

The teacher calls a certain number, then the student whose number corresponds to reports or presents the results of group collaboration to the entire class and the other group gives a response. After that, the teacher appoints another number to explain the results of the group's work.

Cooperative Thinking Share (TPS) type was first developed by Frang Lyman and colleagues at the University of Maryland, according to Arends in Trianto (2007: 61) that, think-pair-share is an effective way to vary the atmosphere of the pattern discussion, and give students more time to think, to respond and help each other. Use of polling stations to compare overall group questions and answers. The syntax or steps of holding the Think-Pair-Share discussion model According to Majid, Abdul (2013: 191-192) that the steps of TPS learning are as follows.

\section{Stage 1: Thinking}

The teacher asks questions or issues related to the lesson, then students are asked to think about the question or issue independently for a while.

\section{Stage 2: Pairing}

The teacher asks students to pair up with other students to discuss what they have thought in the first stage. Interaction at this stage is expected to share answers if a question has been raised, or share ideas if a specific problem has been identified. Usually, the teacher gives 4-5 minutes to pair up. 


\section{Stage 3: Sharing}

In the final stage, the teacher asks the couple to share with the whole class what they have talked about. This is quite effective if done by taking turns between pairs after pairs, and continuing until around a quarter of the couples have had the opportunity to report.

The objectives to be achieved from this study are as follows:

1. To determine whether or not there are differences in mathematics learning outcomes between students using the NHT type of cooperative learning model, type of polling station and the type of Direct Instruction on class VIII students of SMP Negeri 2 Sleman even in the 2015/2016 academic year.

2. To find out the effectiveness of the cooperative learning type NHT and type of polling station compared to the type of Direct Instruction on the mathematics learning outcomes of eighth-grade students of SMP Negeri 2 Sleman in the even semester of the 2015/2016 school year

\section{METHODS}

The type of research in this study is quantitative research. Sugiyono (2015: 14) says that quantitative research methods can be interpreted as research methods that are based on positivism philosophy, used to examine certain populations or samples, sampling techniques are generally done randomly, data collection uses research instruments, quantitative data analysis/statistics with the aim to test the predetermined hypothesis. The research design used in this study was an experimental design. According to Sugiyono (2015: 107), experimental research methods can be interpreted as research methods used to find the effect of certain treatments on others under controlled conditions. The experimental design used in this study is True Experimental Design with the type of Posts Only Control Design.

The population in this study were eighth-grade students of SMP Negeri 2 Sleman in the academic year 2015/2016 which were divided into six classes namely class VIII A, VIII B, VIII C, VIII D, VIII E and VIII F with a total of 190 students. The selection of samples in this study was conducted using Purposive Sampling. According to Margono, S. (2010: 128) that, the selection of a group of subjects in Purposive Sampling, is based on certain characteristics that are considered to have a close relationship with the characteristics of the population that has been known before. This technique is done by direct appointment of the population consisting of six classes so that class VIII C is obtained as the experimental class I which will be given the NHT cooperative learning model, class VIII D as the experimental class II which will be given TPS and class VIII cooperative learning models A as a control class that will be given a cooperative learning model of the Direct Learning type.

The data collection techniques used in this study are documentation and tests. Documentation was used to obtain data on students' initial abilities before the research was conducted, the data was taken from the UTS scores of even semester students of Sleman 2 Public Middle School students. While the test is used to determine the students' mathematics learning outcomes by using the NHT type learning model and the TPS type. The instrument of data collection used in this study is a test of mathematics learning outcomes. The test of the research instrument used was the test of item validity, different power tests, and reliability tests. Then for the analysis prerequisite test used is the normality test and test and homogeneity test. Data analysis for hypothesis testing using the F test and the Newman-Keuls Range Test Advanced Test.

\section{RESULT AND DISCUSSION}

\section{Prerequisite Test for Analysis}

\section{a. Normality test}

The results of the normality test results of student mathematics learning outcomes can be seen in Table 1. Based on the table below with a significant level of $5 \%$ obtained $\chi_{\text {count }}^{2}<\chi_{\text {table }}^{2}$, this means that the test scores for the mathematics learning outcomes of the three classes are normally distributed. 
Table 1. Summary of the Normality Test Value Test for Mathematics Learning Outcomes

\begin{tabular}{|l|l|l|l|}
\hline Class & $\boldsymbol{x}_{\text {count }}^{\mathbf{2}}$ & $\boldsymbol{x}_{\text {table }}^{\mathbf{2}}$ & $\begin{array}{l}\mathbf{D k} \\
(\mathbf{k}-\mathbf{1})\end{array}$ \\
\hline Experiment I & 0,1084 & 5,9915 & 2 \\
\hline Experiment II & 0,4301 & 3,8415 & 1 \\
\hline Control & 2,4131 & 5,9915 & 2 \\
\hline
\end{tabular}

\section{b. Homogeneity Test}

Based on the results of the homogeneity test with a significant level of 5\%, the results were obtained $\chi_{\text {count }}^{2}=15,47$ and $\chi_{\text {table }}^{2}=5,99$ so that $15,47>5,99$ so $\chi_{\text {count }}^{2}>\chi_{\text {table }}^{2}$ which means that the three classes have different variances (not homogeneous). According to Irianto, Agus (2009: 231) that if the variance is different and the number of samples per group is not the same, a rescue step is needed, namely by making a transformation (for example, by transforming with logarithms). Based on the above assumptions because the value of student mathematics learning outcomes is not homogeneous, further analysis of data is transformed with logarithms.

\section{Hypothesis testing}

\section{a. Test $\mathbf{F}$}

The test results of the similarity of the average test scores of students' mathematics learning outcomes can be seen in Table 2 .

Table 2. Summary of ANOVA Test Results Value of Mathematics Learning Outcomes Test

\begin{tabular}{|c|c|c|c|c|}
\hline $\begin{array}{c}\text { Source of } \\
\text { Variance }\end{array}$ & $\begin{array}{c}\text { Number of } \\
\text { squares }\end{array}$ & Dk & Mean Square & F \\
\hline Treatment & 0,0464 & 2 & 0,0232 & \multirow{2}{*}{3,7643} \\
\hline Error & 0,5610 & 91 & 0,0062 & \\
\hline Total & 0,6074 & 93 & & \\
\hline
\end{tabular}

Based on the results of the analysis carried out with a significant level of 5\% and degrees of freedom $=(2.91)$, a value was obtained $F_{\text {count }}>F_{\text {table }}$ its mean $\mathrm{H}_{0}$ is rejected. So it can be said that there are differences in the mathematics learning outcomes of students using the cooperative learning type NHT type, the type of polling station, and the type of Direct Instruction on class VIII students of SMP Negeri 2 Sleman even in the 2015/2016 academic year.

b. Test the Advanced Hypothesis (Newman-Keuls Range Test)

The Newman-Keuls Range Test Results of students' mathematics learning outcomes test can be seen in Table 3.

Table 3. Summary of Newman-Keuls Value Test Results of Student Mathematics Learning Outcomes Test

\begin{tabular}{|c|c|c|c|c|c|c|}
\hline Case & Comparison & RST & $\bar{y} l-\bar{y}_{J}$ & Result & $\overline{\boldsymbol{y}}$ & Conclusion \\
\hline Case I & $\mu_{1}$ vs $\mu_{2}$ & 0,0405 & 0,0005 & $\mathrm{H}_{0}$ accepted & 1,9472 & \\
Case II & $\mu_{1}$ vs $\mu_{3}$ & 0,0470 & 0,0471 & $\mathrm{H}_{0}$ rejected & 1,9467 & \multirow{2}{*}{$\mu_{1}=\mu_{2}>\mu_{3}$} \\
\hline Case III & $\mu_{2}$ vs $\mu_{3}$ & 0,0405 & 0,0466 & $\mathrm{H}_{0}$ rejected & 1,9001 & \\
\hline
\end{tabular}

Based on the table above it can be seen that in case I because $0.0005<0.0405$ then H0 $_{0}$ is accepted as meaning $\mu_{1}=\mu_{2}$. In case II because $0.0471>0.0470$ then $\mathrm{H}_{0}$ is rejected and $1.9472>1.9001$ means $\mu_{1}>\mu_{3}$. Whereas in case III because $0.0466>0.0405$ then $\mathrm{H}_{0}$ is rejected and 1.9467> 1.9001 means $\mu_{2}>\mu_{3}$. So, the conclusion $\mu_{1}=\mu_{2}>\mu_{3}$ which means that the mathematics learning outcomes of students who are taught using the TPS cooperative learning model, but the mathematics learning outcomes of students who are taught using the NHT cooperative learning model or type of TPS results are better than students who are taught using the type of cooperative learning model (Direct Learning ). 


\section{CONCLUSION}

Based on the results of research and discussion, it can be concluded as follows:

1. There are differences in the mathematics learning outcomes of students using the cooperative learning type NHT, TPS and the type of Direct Instruction on class VIII students of SMP Negeri 2 Sleman on the even semester of the 2015/2016 school year.

2. Mathematics learning outcomes of students using the NHT type cooperative learning model are as good as mathematics learning outcomes of students who use TPS cooperative learning models, but the mathematics learning outcomes of students who use the NHT cooperative learning model or TPS type are better than students' mathematics learning outcomes who used the cooperative learning model type Direct Instruction (VIII) in class VIII SMP Negeri 2 Sleman even semester 2015/2016 academic year.

\section{REFERENCES}

Irianto, Agus. 2009. Statistik. Jakarta: Kencana.

Majid, Abdul. 2013. Strategi Pembelajaran. Bandung: PT Remaja Rosdakarya.

Margono, S. 2010. Metodologi Penelitian Pendidikan. Jakarta: PT Rineka Cipta.

Shoimin, Aris. 2014. 68 Model Pembelajaran Inovatif dalam Kurikulum 2013. Yogyakarta : Ar-Ruzz Media.

Sugiyono. 2015. Metode Penelitian Pendidikan (Pendekatan Kuantitatif, Kualitatif dan R\&D). Bandung: Alfabeta.

Suherman, Erman, dkk. 2003. Strategi Pembelajaran Matematika Kontemporer. Bandung: Universitas Pendidikan Indonesia.

Suprijono, Agus. 2009. Cooperative Learning. Yogyakarta: Pustaka Pelajar.

Trianto. 2007. Model-Model Pembelajaran Inovatif Berorientasi Konstruktivistik. Jakarta: Prestasi Pustaka. 